\title{
The fisheries productivity of purse seine in TPI Kranji Paciran, Lamongan
}

\author{
Nova Elasari ${ }^{*}$, Asri Sawiji ${ }^{1}$, Toha Muslih ${ }^{2}$ \\ Marine Science Department, Faculty of Science and Technology, UIN Sunan Ampel Surabaya, Indonesia \\ ${ }^{2}$ Marine and Fishery Office of Lamongan Regency, Indonesia \\ *E-mail: novaelasari4202@gmail.com
}

\begin{abstract}
Fisheries productivity plays an important role in national development. The potential of fisheries in Indonesia is quite large so that many coastal communities depend on their lives from fishing activities. East Java province has a fishery area that is quite potential with the availability of considerable human resources, one of them is Lamongan. This research was conducted in Fish Auction Site (Tempat Pelelangan Ikan, TPI) Kranji, Lamongan. The purpose of this study is to find out the productivity value of purse seine fisheries in TPI Kranji based on the size of the ship and the fishing trip. This research was conducted by survey method to know the condition of purse seine fishery in the field directly. Purse seine fishing vessels located in TPI Kranji in 2020 as many as 32 ships that have gross tonnage (GT) of 9 to 24 GT. The dominant catches are Longtail Tuna (Thunnus tonggol), Mackerel Tuna (Euthynnus affinis), Fringescale Sardinella (Sardinella fimbriata), Short Mackerel (Rastrelliger brachysoma) and Goldstripe Sardinella (Sardinella gibbosa). There are two seasons in the fishing process at TPI Kranji, the regular season (Fringescale Sardinella) and the peak season (Tuna) The highest value of productivity per trip was obtained 1.59 tons / trip / year which occurred in 2019 with 223 of fishing trips and the amount of catch production of 356.71 tons. The highest value of productivity per GT occurred in 2020, obtained 2.09 tons / GT / year, which currently has 32 purse seine vessels. The productivity per GT from year to year is increasing because the amount of production is also increasing every year.
\end{abstract}

Keywords: purse seine, catch fisheries, productivity, TPI Kranji.

\section{INTRODUCTION}

East Java province has a fishery area that is quite potential with the availability of considerable human resources. One of the areas in East Java Province that has considerable marine fishery development potential is in Lamongan Regency. Lamongan regency has abundant potential in the catch fishery sector and is supported by proper handling and utilization with the support of modern technology. With a fleet of fishing vessels as many as 3,344 units, and with fishing equipment as many as 3,825 units and supported by five fish auction sites (Tempat Pelelangan Ikan, TPI) [1]. One of the fish auction site in Lamongan Regency is TPI Kranji. TPI Kranji is one of the fish landing centers in East Java Province with facilities that function properly and can be reached by fishing boats from various places [2]. Various types of fishing equipment used by fisher Paciran District to catch fish are lampara, purse seine, gill net, tuna long line, portable trap and trammel net. For the fishing gear that dominates in TPI Kranji is purse seine. This capture tool has a large contribution of catches in TPI Kranji.

Year to year the purse seine fishing equipment continues to develop, not only in shape but also the materials and vessels used for its capture. Purse seine fishing equipment belongs to the group of surrounding nets in which the net will form a fence that has hordes of fish caught [3]. Purse seine fishing equipment is effective enough to catch pelagic fish whose behavior is grouped in large sizes both on the coast and offshore [4], so that fisher are more dominant in using purse seine fishing equipment in increasing fishing efforts. Catching efforts is a benchmark to produce a number of catches or productivity benchmarks from fishing units [5].

According to the Decree of the Minister of Marine Affairs and Fisheries NUMBER 86 / KEPMENKP / 2016 concerning The Productivity of Fishing Vessels, the productivity of fishing vessels is the level of ability to produce fish caught determined by considering the size of the ship, the type of material, the strength of the ship's engine, the type of fishing equipment used, the number of trips per year, the average production result per trip and the area of fishing. The productivity of fishing vessels is determined per Gross Tonnage (GT) per year based on the calculation of total catches per ship in one year divided by the size of the GT of the ship concerned. As for the measurement of productivity of fishing equipment including productivity per unit of capture equipment, productivity per ship crew [5]. The potential resources of pelagic fish in Kranji waters and the growing fishing efforts using purse seine fishing equipment in the Kranji TPI region, so it is necessary to conduct research on the productivity of purse seine catching both by the fishing trips and the size of the vessels. 


\section{METHODS}

\section{Time and Location of Survey}

This research was conducted at TPI Kranji, Paciran District, Lamongan Regency by survey method, looking at the condition of purse seine catch fishery in the field directly. The time for field survey is two months, from August 2020 to October 2020. The research location can be seen in Figure-1.

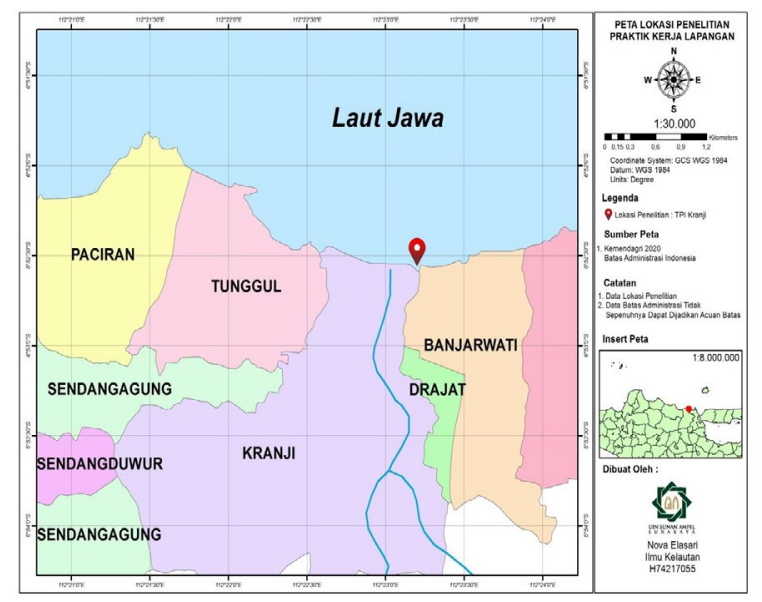

Figure-1. Research Locations Map

\section{Data Collection}

The data needed in this study are primary and secondary data. Data collection in this study was conducted by observation and interview. The observation process carried out by looking at the condition of purse seine fishery, construction of fishing equipment, operation of fishing equipment, construction of purse seine vessels, and purse seine catches. As well as following the process of weighing the catch to see how many species are caught.

Interviews in this research were conducted by conducting interviews with several speakers such as the chairman of fisher, ship crew, ship owners, agents and some staff of TPI Kranji. The data obtained include information about the capture equipment in the form of length and height of net, the size of the net eye and other components of the capture tool. Ship data obtained in the form of length, width and in-ship, the needs of ships such as fuel and other ship components. As for secondary data taken during the study such as reports of purse seine fishery production over the past three years and other sources of information. Secondary data collection techniques can use data through books, literatures, and journals related to this research.

\section{Data Analysis}

Data processing in this study was conducted using Microsoft Excel 2010 software. Data processing includes calculation of productivity per trip and productivity per ship GT. Productivity analysis of purse seine can be done with data of purse seine ship production per trip and production per ship size within a year. According to the Decree of the Minister of Marine Affairs and Fisheries Number 61/KEPMEN-KP/2014, the productivity of fishing vessels is determined per GT per year based on the calculation of the number of catches per ship in one year divided by the GT of the vessel concerned, as shown in the Equation (1) and (2).
Productivity in trip $=$

Productivity in GT =

$$
\frac{\text { average production (ton/trip/yr) }}{\text { average fishing trip }}
$$

$$
\frac{\text { average production (ton } / \text { trip } / y r)}{\text { average ship size }}
$$

\section{RESULTS AND DISCUSSION \\ Purse Seine Fisheries in TPI Kranji}

There are approximately 522 fleets of boats with approximately 7011 fisher [4]. The majority of Kranji villagers are classified as fisher, this is due to the location of Kranji village adjacent to the open water. The dominant and frequently found fishing equipment in TPI Kranji is $a$ purse seine fishing device that operates in the waters around Lamongan and Gresik. In TPI Kranji has a levy fee of $2 \%$ where the cost has been determined by the port.

In TPI Kranji there are several seasons of purse seine catching which include Tuna season and Fringescale sardinella season. Tuna season where the number of fish caught is abundant, in the Tuna season on purse seine catching efforts in TPI Kranji generally occurs in October to April. While this Fringescale sardinella season occurs when the number of catches is not abundant nor does it decrease and the fish caught abundantly this season is Fringescale sardinella fish, which generally occurs in May to September. As for this season, the catch will generally decrease compared to other seasons. There are many types of purse seine catches in TPI Kranji which include Short Mackerel, Goldstripe Sardinella, Tuna, and so on. Tuna fish is the largest production in TPI Kranji because during the Tuna season fisher get abundant Tuna fish catches. The main catch fish after landing at TPI Kranji will be directly under by the agent (steamer) of each ship to be sold to the factory and market. As for the side catches that are generally low selling value will be processed first to be salted fish, flour or other processed.

For the culture that is done every year in TPI Kranji is "Petik Laut". The word "Petik Laut" comes from the Javanese language, where petik has the meaning of pick which means to reap the results of efforts from the sea or laut in Javanese. "Petik Laut" is a gratitude by fisher and villagers that is done every mid-Tuna season as gratitude for the abundant catches. This sea picking ceremony is financed by the fisher themselves where each fishing boat that makes the catch will be cut by several percent of the catch. The money is used for celebrations once a year. The celebration will be held puppet show and recitation held for the people of Kranji remain grateful to the Almighty.

\section{Productivity of Purse Seine Fisheries in TPI Kranji Productivity per trip}

The productivity level of a purse seine capture unit can be calculated through catch per unit effort. To find out the productivity of purse seine capture in Kranji TPI, it is calculated using the calculation of the average production approach produced by the purse seine capture unit per attempted capture (trip) within one year and production per ship size used within one year. Productivity in the trip from the production of purse seine catches and trip can be seen in the Table-1. 
Table-1. Productivity of purse seine

\begin{tabular}{|c|r|r|r|}
\hline Year & $\begin{array}{c}\text { Production } \\
\text { (ton/year) }\end{array}$ & $\begin{array}{c}\text { Trip } \\
\text { (per year) }\end{array}$ & $\begin{array}{c}\text { Productivity } \\
\text { (ton/trip/ } \\
\text { year) }\end{array}$ \\
\hline 2018 & 271.56 & 190 & 1.42 \\
\hline 2019 & 356.71 & 223 & 1.59 \\
\hline $\begin{array}{c}\text { January- } \\
\text { August } \\
2020\end{array}$ & 268.69 & 169 & 1.58 \\
\hline
\end{tabular}

Table-1 shows that the productivity per trip of thefishing unit purse seine at TPI Kranji has increased over the last 3 years. The lowest productivity occurred in 2018, namely 1.42 tons / trip / year with a total production of 271.56 tons in a year and a number of trips of 190 trips in a year. Then in 2018 the productivity increased by 1.59 with a total of 223 trips and a catch production of 356.71 tons for a year. Whereas in 2020 the productivity per trip was different from 0.01 in the previous year, namely 1.58 with 169 trips and 268.69 tonnes of production. In 2020, productivity is still considered to be increasing with the result of productivity being lower than the previous year but only a small difference. This is because the research was carried out from August to October 2020. And the data on the production of TPI Kranji's catch is available only until August 2020, which means that the productivity of trips in 2020 is only per eight months.

The productivity value per trip during the study shows that the more fishing effort (trip), the higher the productivity value. This is because the more trips in a year, the more catches will be. The number of trips each year always changes according to the season. There are two division of seasons in the fishing process at TPI Kranji, namely the regular season (Fringescale Sardinella) generally occurs between May and September, while the peak season (Tuna) will occur from October to April. The average number of trips in each month ranges from 15-20 trips. For the remaining days it is generally used to repair damaged nets because at the same time there is a bright moon which causes the catch to be less than optimal if the fishing process is still carried out. For Kranji fisher, if the catch is abundant, generally in a day they will make two trips if the sun has not set.

\section{Productivity per GT}

Productivity per GT in this research uses the calculation of the average catch obtained byvessels purse seine in a year and then divided by the average size of thevessels purse seine used by Kranji fisher in a year. The average size of the vessels used over the three years was 16 GT. Every year several Kranji fishing boats increase the size of the GT but only slightly. The productivity per GT from year to year is increasing, this is because the amount of production is also increasing every year. The highest productivity per GT occurred in 2020, namely 2.09 tonnes / GT / year, which currently has 32 purse seine vessels. For the lowest productivity per GT in 2018, namely 1.41 tons / GT / year, at that time the number of purse seine vessels was 35 vessels. This shows that in 2020 it can make the most of the capacity of a 16 GT vessel. During the last three years, the average GT used by Kranji fisher is $16 \mathrm{GT}$, but the amount of catch production per year has continued to change, this shows that the size of the catch is not only determined by the size of the GT of the ship used. However, there are several other factors, namely the fishing trip, the number of crew members, and others.

Ships with a larger GT size are generally able to carry more crew members and are also able to accommodate more catches [3]. The shape and size of a ship will affect the strength and movement of ships over the sea, ships with large capacities are able to operate further from land and will also affect the catch of fisher. According to the results of interviews with several fisher, it is said that several vessels purse seine each year will increase the size of the GT so that they can sail further. Until now the fishing area for the purse seine of TPI Kranji fisher is only limited to Lamongan waters, in contrast to the ships belonging to the Port of Brondong which have a larger GT size than the fishing boats Kranji generally have fishing areas in Bawean waters and Madura waters (Masalembu island).

\section{CONCLUSIONS}

Purse seine fishing vessels located in TPI Kranji in 2020 as many as 32 ships that have gross tonnage (GT) of 9 to 24 GT. The dominant catches are Longtail Tuna (Thunnus tonggol), Mackerel Tuna (Euthynnus affinis), Fringescale Sardinella (Sardinella fimbriata), Short Mackerel (Rastrelliger brachysoma) and Goldstripe Sardinella (Sardinella gibbosa). There are two seasons in the fishing process at TPI Kranji, the regular season (Fringescale sardinella) and the peak season (Tuna).

The highest value of productivity per trip was obtained 1.59 tons / trip / year which occurred in 2019 with 223 of fishing trips and the amount of catch production of 356.71 tons. The lowest productivity occurred in 2018 obtained 1.42 tons / trip / year with a total production of 271.56 tons in a year and 190 trips in a year. The highest value of productivity per GT occurred in 2020, obtained 2.09 tons / GT / year, which currently has 32 purse seine vessels. The lowest productivity per GT occurred in 2018, obtained 1.41 tons / GT / year, at that time the number of purse seine vessels was 35 vessels. The productivity per GT from year to year is increasing because the amount of production is also increasing every year.

\section{REFERENCES}

[1] Marine and Fishery Office of Lamongan Regency. 2020. Fisheries Profile. Lamongan.

[2] Mas'ud, F. \& A. Premadi. 2016. The influence of marketing on the sale of fish catches at the fish landing base in the village of Kranji, Paciran District Lamongan Regency. Scientific Journal of The Faculty of Animal Husbandry. 7(1): 11-19. https://doi.org/10.30736/grouper.v7i1.44

[3] Alhuda, S., Z. Anna, and I. Rustikawati. 2016. Analysis of the productivity and business performance of purse seine fisherman at the Lempasing Coastal Fishing Port, Bandar Lampung. Journal of Marine Fisheries. 8(1): 30-40.

[4] Sanyio, H., B. A. Wibowo, and I. Setiyanto. 2019. Financial Analysis of Purse Seine Capture Fisheries at TPI Kranji Lamongan, East Java. Journal of Fisheries Resources Utilization Management and 
Technology. 8(1): 25-34.

[5] Limbong, I., E. S. Wiyono, \& R. Yusfiandayani. 2017. Factors affecting the production of purse seine units in PPN Sibolga, North Sumatera. ALBACORE Marine Fisheries Research Journal. 1(1): 89-97. 